\title{
SEKOLAH KAPITALISME YANG LICIK
}

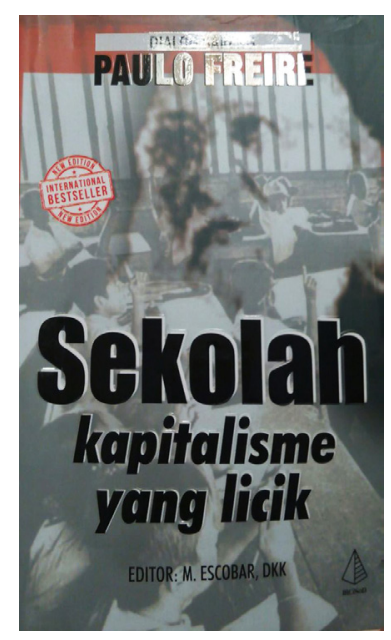

$\begin{array}{ll}\text { Editor } & \text { : Miguel Escobar dkk } \\ \text { Penerbit } & \text { : IRCiSoD (Bekerja sama dengan LKiS) } \\ \text { Tempat terbit } & \text { : Jakarta } \\ \text { Tahun terbit } & : 2016 \\ \text { Tema } & : \text { Pendidikan dan Masyarakat } \\ \text { Deskripsi } & : \text { xlviii, 256 hlm ; 12 x } 18 \mathrm{~cm} \\ \text { ISBN } & : \text { 978-602-279-238-3 } \\ \text { Dirisensi Oleh } & \text { : Noviansyah }\end{array}$

Bagian pertama buku ini membahas tentang Pendidikan dan Kekuasaan, Bagian kedua Kurikulum dan Realitas Sosial dan ditutup pada bagian ketiga peran para intelektual Buku ini terlahir sebagai sebuah kesaksian dan evident dialog pemikiran politik dan edukatif sekelompok cendikiawan di University Nacional Automa of Mexico (UNAM) yang ketika itu menghadirkan seorang praksis pendidikan pembebasan sekaligus pendidik humanistik kontemporer, Paulo Freire. Secara substantif buku ini memuat dialog yang mengemukakan tentang tiga persoalan utama dunia pendidikan ; kekuasaan dan pendidikan, kurikulum dan realitas sosial dan peran intelektual yang diperkaya dan diperluas melalui pengetahuan tentang emansipasi pendidikan (mandiri).

Namun debat yang dituangkan melalui buku ini dapat membantu mengekplorasi kajian mengenai peran universitas didalam budaya Amerika Utara kontemporer sekaligus memposisika pendidik Amerika Latin dalam lingkungan pos-modernisme serta turut mengkritisi eksistensi lembaga pendidikan / akademi. Bahwa telah saatnya universitas / akademi didorong untuk menjadi benar-benar plural dan dialogis sehingga memberikan kemampuan yang tidak sekedar untuk membaca buku namun juga memahami konteks (situasi). 